\title{
Once-daily tobramycin in the treatment of adult patients with cystic fibrosis
}

\author{
A. Whitehead*, S.P. Conway", C. Etherington", N.A. Caldwell ${ }^{\mp}$, N. Setchfield ${ }^{+}$, S. Bogle ${ }^{\S}$
}

Once-daily tobramycin in the treatment of adult patients with cystic fibrosis. A. Whitehead, S.P. Conway, C. Etherington, N.A. Caldwell, N. Setchfield, S. Bogle. (C) ERS Journals Ltd 2002.

ABSTRACT: The aim of this study was to test the equivalence of once- and thrice-daily dosing with tobramycin by comparing efficacy and safety in adult patients with cystic fibrosis.

Sixty adult patients with an acute respiratory exacerbation were randomized to receive either $10 \mathrm{mg} \cdot \mathrm{kg}^{-1}$ tobramycin once-daily or $3.3 \mathrm{mg} \cdot \mathrm{kg}^{-1}$ tobramycin thricedaily. Primary efficacy and safety endpoints were defined as changes in respiratory function and changes in renal function and hearing.

Both groups showed a significant increase in respiratory function without a clinically significant change in renal function. For changes in forced vital capacity $\%$ predicted and serum potassium and magnesium levels, equivalence was demonstrated. For the variables forced expiratory volume in one second and forced mid-expiratory flow \% pred and serum creatinine levels, there was insufficient power to demonstrate equivalence. One patient in each group showed bilateral impairment in pure tone audiogram after treatment.

This study demonstrated significant clinical improvement with both once- and thricedaily tobramycin dosing. Equivalence between the two regimens was shown for some, but not all primary endpoints. Once-daily dosing should be used with careful monitoring of safety and efficacy until large multicentre studies confirm these encouraging results. Eur Respir J 2002; 19: 303-309.
*Dept of Pharmacy, Leeds Teaching Hospitals, Leeds, " Regional Adult Cystic Fibrosis Unit, Seacroft Hospital, Leeds, "Dept of Pharmacy, Wirral Hospital, Merseyside, and Dept of Pharmacy and Chemistry, Liverpool John Moores University, Liverpool, ${ }^{+}$Dept of Audiology, St James's Hospital, Leeds, ${ }^{\S}$ Aysgarth Statistics, Beaconsfield, UK.

Correspondence: S.P. Conway, Seacroft Hospital, York Road, Leeds, LS14 6UH, UK

Fax: 441132063738

E-mail: steven.conway@leedsth.nhs.uk

Keywords: Aminoglycosides cystic fibrosis

tobramycin

Received: March 62001

Accepted after revision September 17 2001
In most adult patients, cystic fibrosis $(\mathrm{CF})$ is characterized by recurrent acute pulmonary exacerbations. Pseudomonas aeruginosa is the most common pathogen and is usually treated with a combination of an aminoglycoside and a $\beta$-lactam antibiotic, due to their synergistic activity. Tobramycin is the aminoglycoside of choice, since it shows good activity against $P$. aeruginosa and has relatively low toxicity. It is usually administered as $10 \mathrm{mg} \cdot \mathrm{kg}^{-1} \cdot \mathrm{day}^{-1}$ in

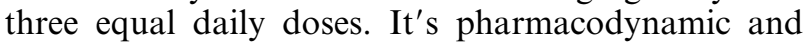
pharmacokinetic properties, however, suggest that once-daily (o.d.) administration would be more effective and less toxic; bactericidal effects depend on peak drug concentration achieved [1], toxicity is related to the amount of drug that accumulates in susceptible end organs [2] and saturation of binding sites during o.d. administration may reduce tissue accumulation [3].

In non-CF patients, meta-analysis has shown that $o . d$. administration is at least as effective and no more toxic than thrice-daily (t.i.d.) administration [4]. These data cannot be extrapolated to patients with CF for several reasons. 1) Aminoglycosides in patients with CF display a larger volume of distribution and a shorter elimination half-life $[5,6]$. Plasma drug concentrations will fall more rapidly due to the latter giving a longer period at the end of the dosing interval, when concentrations are below the minimal inhibitory concentration. This may allow greater regrowth of bacteria. 2) Target serum aminoglycoside concentrations need to be higher in patients with $\mathrm{CF}$ in order to achieve bactericidal activity against mucoid strains of $P$. aeruginosa [5]. Higher doses are therefore needed, typically $\sim 10 \mathrm{mg} \cdot \mathrm{kg}^{-1} \cdot \mathrm{day}^{-1}$ in $\mathrm{CF}$ patients [7] and $3-5 \mathrm{mg} \cdot \mathrm{kg}^{-1} \cdot \mathrm{day}^{-1}$ in non-CF patients [8] (Eli Lilly, Nebcin data sheet). As higher peak drug concentrations are likely to occur in these circumstances, it is necessary to confirm that there is no greater incidence of adverse events. 3) Typical courses of treatment in $\mathrm{CF}$ last $12-14$ days compared to 5-10 days in the studies of patients without CF $[4,8]$. The incidence of side-effects may also be higher with longer courses. Patients with $\mathrm{CF}$ also undergo repeated treatment courses.

The aim of this study was to test the equivalence of $o . d$. administration of tobramycin with the usual t.i.d. dosing regimen in adult patients with $\mathrm{CF}$ and an acute respiratory exacerbation. For the equivalence trial, the null hypothesis was that the new treatment would be worse than the standard (defined here as below the tolerance limit of $-10 \%$ ) and the alternative hypothesis was that the two treatments would be equivalent. The treatments were compared for safety and efficacy. 


\section{Methods}

\section{Study subjects}

All patients with chronic $P$. aeruginosa infection and an acute respiratory exacerbation whose most recent sputum sample showed sensitivity to tobramycin and a $\beta$-lactam antibiotic, were invited to enter the study over a 17-month period. Antibiotic resistance was assessed by the Stokes' disc diffusion method. Sixty patients were recruited. The diagnosis of $\mathrm{CF}$ in each case was confirmed by two abnormal sweat tests or by identification of two CF transmembrane regulator gene mutations.

An acute infective pulmonary exacerbation was defined by at least four of the following: increased sputum volume; a change in sputum colour, measured on a scale from clear to dark green; increased cough; a $>10 \%$ fall in respiratory function (forced expiratory volume in one second (FEV1)); decreased exercise tolerance; and decreased appetite or loss of weight. Patients who were either colonized with Burkholderia cepacia or Stenotrophomonas maltophilia or had been treated with additional antibiotics in the previous month were excluded from the study.

\section{Study design}

Patients were randomized, using a random number table, to receive either $10 \mathrm{mg} \cdot \mathrm{kg}^{-1} \cdot \mathrm{day}^{-1}$ tobramycin o.d. $(\mathrm{n}=34)$ or $3.3 \mathrm{mg} \cdot \mathrm{kg}^{-1}$ tobramycin t.i.d. to the nearest $20 \mathrm{mg} \quad(\mathrm{n}=26)$, and a $\beta$-lactam antibiotic (either piperacillin $4 \mathrm{~g}$ t.i.d., tazocin $4.5 \mathrm{~g}$ t.i.d., aztreonam $2.5 \mathrm{~g}$ t.i.d., azlocillin $5 \mathrm{~g}$ t.i.d., imipenem $1.5 \mathrm{~g}$ t.i.d., meropenem $2 \mathrm{~g}$ t.i.d. or ceftazidime $200 \mathrm{mg} \cdot \mathrm{kg}^{-1} \cdot \mathrm{day}^{-1}$ in three equally divided doses), according to sensitivity results. There was no imbalance between the two treatment groups in patient age (o.d. mean 21 yrs (range: 16-32) versus t.i.d. mean 22 yrs (15-47)), weight (55.3 kg (40-73) versus $54.0 \mathrm{~kg}$ (38.5-76)), Northern chest radiograph score (11 (5-16) versus 15 (5-16)) [9], and Shwachman-Kulczycki score (75 (45-90) versus 70 (45-90)) [10]. The o.d. group had a higher, but not clinically significant, mean C-reactive protein (CRP) level $\left(39 \mathrm{mg} \cdot \mathrm{L}^{-1}(10-131)\right.$ versus $\left.35 \mathrm{mg} \cdot \mathrm{L}^{-1}(10-233), \mathrm{p}=0.02\right)$. Treatment was given for 12 days in hospital. At entry patients, were asked if they would prefer an o.d. or t.i.d. regimen, assuming equal efficacy, which did not affect randomization.

Efficacy was assessed by comparing the baseline and post-study measurements of: primary endpoints, FEV1 \% predicted, forced vital capacity (FVC) and forced mid-expiratory flow $(\mathrm{FEF} 25-75 \%)$, and the secondary endpoints, CRP, peripheral white blood cell count and percentage neutrophil count, body mass index (BMI), and clinical score [11]. Renal toxicity, caused by the treatment, was assessed by changes in serum creatinine, potassium and magnesium concentrations. Ototoxicity was assessed by baseline and post-treatment audiograms, with frequencies between $1,000-8,000 \mathrm{~Hz}$. The audiologist was blinded to the patient's treatment regimen. Because of the logistical difficulties and likely inaccuracies involved in performing audiograms in acutely ill patients, baseline audiograms were obtained during routine outpatient visits before admission. Post-treatment audiograms were performed $\geqslant 2$ weeks after the end of treatment. The pure tone audiogram was performed using a Kamplex AD17 diagnostic (Interacoustics, Assens, Denmark/PC Worth, London, UK; calibrated yearly to the required British Standard) and a Modified Hughson Westlake method, performed to the British Society of Audiology standard. Hearing impairment was defined as a bilateral change at $\geqslant 2$ frequencies of $15 \mathrm{~dB}$ or $\geqslant 1$ frequency of $20 \mathrm{~dB}$. Patients were questioned about any new symptoms of dizziness, vertigo and tinnitus on days 1, 7, and 12 .

\section{Tobramycin administration and level sampling}

It is common practice in the UK to administer divided doses either as a bolus or as a 30-min infusion. A longer infusion period was used for the $o . d$. regimen to reduce the influence of the distribution phase, by allowing the drug to distribute within the tissue compartment as rapidly as it was being administered [12]. The o.d. and t.i.d. doses were administered over 60 and $30 \mathrm{~min}$, respectively, in $50 \mathrm{~mL} \mathrm{NaCl}(0.9 \%)$.

Tobramycin levels were determined by immunoassay using the Abbott AxSym (Abbott Laboratories, Maidenhead, UK). Calibration and controls were performed in accordance with the manufacturer's guidelines and laboratory protocols. In the t.i.d. group, tobramycin levels were taken $30 \mathrm{~min}$ after the end of the fourth or fifth dose and immediately before the subsequent dose. The exact time of sample collection was noted. Target peak and trough levels were $10-12 \mathrm{mg} \cdot \mathrm{L}^{-1}$ and $<2 \mathrm{mg} \cdot \mathrm{L}^{-1}$, respectively.

There is no uniform method of monitoring aminoglycoside concentrations to ensure optimum efficacy and safety with o.d. dosing [13]. PRINS et al. [8] gave divided doses of gentamicin and o.d. therapy as 30-min infusions, with peak concentrations sampled 30 min after complete administration. SAwCHUK et al. [14] administered gentamicin over $60 \mathrm{~min}$, with sampling at 0,1 and $3 \mathrm{~h}$ postcompletion. In the absence of a clear consensus, a common sense approach was applied to ensure that distribution was complete when samples were drawn and that the rate of concentration decline this measured was a reflection of renal elimination. The basis of this study was to define the individual pharmacokinetic parameters of the elimination rate constant $(\mathrm{k})$ and the volume of distribution. This is most accurate when distribution is complete. If samples had been drawn early, estimates of $\mathrm{k}$ would have been falsely elevated.

To the best of the authors' knowledge, until now, the distribution time for $10 \mathrm{mg} \cdot \mathrm{kg}^{-1}$ of tobramycin has not been defined in an adult population with CF. Therefore, a cautious approach was used to obtain more reproducible results. The peak sample in the o.d. group was taken 60 min after the end of the 60 -min infusion so that the drug had fully completed the distribution phase and begun the elimination phase. A second sample was taken $5 \mathrm{~h}$ after the first sample. 
To ensure that there was no serum tobramycin accumulation, the data were extrapolated to estimate the time when tobramycin serum concentrations fell to $1 \mathrm{mg} \cdot \mathrm{L}^{-1}$. From the two measured serum concentrations in both groups, $\mathrm{k}$ and mean elimination half-life were calculated using a one-compartment model with a modified two-point Sawchuk-Zaske method (see Appendix) [15]. Serum tobramycin concentration monitoring was repeated in the second week of treatment.

\section{Statistical analysis}

The effect of each treatment schedule was tested by comparing day 12 results with baseline, using the paired t-test (confirmed by the Wilcoxon matchedpairs signed-rank test when normality was in doubt) separately for each group. The percentage changes for each patient were calculated and summarized for each group. The size of the treatment effect was estimated as the difference between the means for the two groups, with SE and 95\% confidence intervals (CI). For variables where a change in one direction corresponded to an improvement, a one-sided CI was given. For serum concentrations where too large a change in either direction would be unsafe, a twosided CI was given.

The two groups were compared using a test for equivalence. To test equivalence, the largest acceptable difference in outcome (change from baseline) between the groups was $\pm 10 \%$ of baseline. A total sample size of 206 patients was required to reject this difference in improvement in FEV1 (admission mean $=1.72 \mathrm{~L}$, mean change $=0.29 \mathrm{~L}, \mathrm{SD}=0.38 \mathrm{~L}$, from previous data for t.i.d. treatment) between unpaired groups with a power of $90 \%$ at the $2.5 \%$ significance level (one-sided test). A total sample size of 92 patients would be needed to test equivalence if the largest acceptable difference in outcome between the groups was $\pm 15 \%$. The two-sample t-test was used, confirmed by the Mann-Whitney U-test when normality was in doubt. This compared the null hypothesis that the mean percentage change with o.d. treatment would be worse than with t.i.d. treatment, with the alternative hypothesis that $o . d$. dosing would be equivalent or better.

A one-sided t-test was used for variables where a change in one direction corresponded to an improvement. For serum concentrations where too large a change in either direction would be unsafe, two onesided t-tests were used with null hypotheses corresponding to each of the tolerance limits $(+10 \%$ and $-10 \%)$. For consistency with the CIs, a p-value of $0.025 \%$ was regarded as the cut-off for significance. The study was approved by the hospital ethical committee and written informed consent was obtained from patients.

\section{Results}

There was a significant increase in FVC, FEV1 and FEF $25-75 \% \%$ pred and BMI. A significant fall was also seen in clinical score, peripheral blood white cell and \% neutrophil count, and CRP level in both treatment groups. There was no clinically significant change in serum potassium, magnesium or creatinine levels (table 1). Equivalence (i.e. that o.d. administration of tobramycin was at least as effective and/or as safe as t.i.d. administration) was demonstrated in FVC \% pred, BMI, serum potassium and magnesium, and CRP levels. The conclusion of equivalence for magnesium level was based on the Mann-Whitney U-test, since the distribution for $o$.d. was skewed by outliers. There was insufficient power to demonstrate equivalence for the variables FEV1 and FEF25-75\% \% pred, clinical score, peripheral white blood cell and \% neutrophil count, and serum creatinine level (table 2).

No patients in either group reported symptoms of dizziness, vertigo, or tinnitus. The logistics of audiometry meant that only 18 patients in the o.d. group and 10 patients in the t.i.d. group were tested. One patient in each group fulfilled the criteria for hearing impairment.

Sixty patients were entered into the study. Thirtyfour were randomized to the o.d. and 26 to the t.i.d. regimen. Eleven patients (four from the o.d. group and seven from the t.i.d. group), were withdrawn. Eight patients (four o.d. group, four t.i.d. group) were withdrawn due to the development of $P$. aeruginosa resistance to tobramycin in sputum, sampled during the study. One patient (t.i.d. group) was withdrawn when intravenous colomycin was prescribed concurrently and the dose of tobramycin was therefore reduced. Two patients refused to continue on a t.i.d. regimen. Thirty patients received o.d. and 19 t.i.d. tobramycin. Seventy-eight per cent of patients said they would prefer an $o . d$. regimen, $6 \%$ a t.i.d. regimen, and $16 \%$ had no preference. There was no significant difference in the prevalence of respiratory tract infection with Staphylococcus aureus between the two groups $(19(63 \%)$ patients in the o.d. group and $13(68 \%)$ patients in the t.i.d. group). In the t.i.d. group, mean tobramycin dose was $10.3 \mathrm{mg} \cdot \mathrm{kg}^{-1} \cdot \mathrm{day}^{-1}$. Five patients needed a dose adjustment. Three had high peaks $\left(12.6,13.1\right.$ and $\left.17.4 \mathrm{mg} \cdot \mathrm{L}^{-1}\right)$ requiring a decreased dose, and two had high troughs (2.1 and $2.2 \mathrm{mg} \cdot \mathrm{L}^{-1}$ ) requiring a change to twice-daily dosing. In the second week, two patients needed a dose adjustment. Both had high troughs (2.2 and $\left.2.3 \mathrm{mg} \cdot \mathrm{L}^{-1}\right)$.

In the o.d. group, the mean dose was $9.7 \mathrm{mg} \cdot \mathrm{kg}^{-1}$. No patients needed dose adjustments in either the first or second weeks. There was no statistical difference between the first and repeat levels in either the t.i.d. or $o . d$. groups. Details of the pharmacokinetic parameters are shown in table 3 .

\section{Discussion}

Patients in both treatment groups showed significant clinical improvement. o.d. treatment with tobramycin was shown to be equivalent to t.i.d. dosing for changes in mean FVC \% pred, BMI, and CRP levels. To the authors' knowledge, there is no previous clinical study of $o . d$. administration of 
Table 1. - Within group summaries and tests

\begin{tabular}{|c|c|c|c|c|c|c|c|c|c|c|c|c|c|}
\hline & & \multicolumn{3}{|c|}{ Day 0} & \multicolumn{3}{|c|}{ Day 12} & \multicolumn{3}{|c|}{ Change } & \multicolumn{3}{|c|}{ Within group } \\
\hline & & $\mathrm{n}$ & mean & SD & $\mathrm{n}$ & mean & SD & $\mathrm{n}$ & mean & SD & $\begin{array}{c}\text { Paired } \\
\text { t-test }\end{array}$ & Wilcoxon & Conclusion \\
\hline \multirow[t]{2}{*}{ BMI } & o.d. & 24 & 19.8 & 2.4 & 25 & 20.3 & 2.3 & 24 & 0.542 & 0.571 & 0.00001 & & I \\
\hline & t.i.d. & 17 & 19.9 & 2.5 & 13 & 20.2 & 2.64 & 13 & 0.537 & 0.736 & 0.004 & & I \\
\hline \multirow[t]{2}{*}{ FVC \% } & o.d. & 30 & 56.6 & 19.9 & 30 & 71.2 & 20.3 & 30 & 14.3 & 14.8 & 0.000004 & 0.000004 & I \\
\hline & t.i.d. & 18 & 66.1 & 23 & 16 & 80.7 & 22.4 & 16 & 12.2 & 14.2 & 0.0004 & 0.0006 & I \\
\hline \multirow[t]{2}{*}{ FEV1 \% } & o.d. & 30 & 40.3 & 16.6 & 30 & 50.8 & 20.3 & 30 & 10.1 & 12.3 & 0.00004 & 0.000005 & I \\
\hline & t.i.d. & 18 & 47.9 & 20.8 & 16 & 59.5 & 23 & 16 & 9.66 & 11.3 & 0.0005 & 0.0009 & I \\
\hline \multirow[t]{2}{*}{ FEF $25-75 \%$} & o.d. & 30 & 20.8 & 14.5 & 30 & 26 & 21.9 & 30 & 5.15 & 12.1 & 0.020 & 0.017 & I \\
\hline & t.i.d. & 18 & 24.8 & 15.6 & 16 & 32.3 & 22.1 & 16 & 6.39 & 10.6 & 0.009 & 0.011 & I \\
\hline \multirow[t]{2}{*}{ Score } & o.d. & 29 & 8.24 & 2.44 & 21 & 4.26 & 2.54 & 21 & -3.96 & 2.99 & 0.000002 & 0.00003 & D \\
\hline & t.i.d. & 18 & 8.44 & 3.48 & 9 & 4.14 & 3.06 & 9 & -3.86 & 2.38 & 0.00004 & 0.001 & D \\
\hline \multirow[t]{2}{*}{ WCC } & o.d. & 29 & 11.3 & 3.1 & 25 & 8.61 & 2.75 & 25 & -2.31 & 3.38 & 0.001 & 0.0005 & D \\
\hline & t.i.d. & 18 & 10.2 & 4.66 & 14 & 6.28 & 1.41 & 14 & -4.27 & 4.51 & 0.0006 & 0.0003 & D \\
\hline \multirow[t]{2}{*}{ Neut. \% } & o.d. & 28 & 72.9 & 8.79 & 25 & 62.6 & 11.6 & 25 & -10.6 & 14.2 & 0.001 & & D \\
\hline & t.i.d. & 18 & 73.8 & 8.63 & 14 & 61.3 & 7.13 & 14 & -12.3 & 10.0 & 0.0005 & & D \\
\hline \multirow{2}{*}{ CRP } & $o . d$. & 29 & 39.2 & 31.3 & 23 & 13 & 6.12 & 23 & -24.0 & 28.0 & 0.0003 & 0.0003 & D \\
\hline & t.i.d. & 17 & 35.7 & 57.5 & 15 & 13.7 & 12.2 & 15 & -25.5 & 56.2 & 0.051 & 0.002 & D \\
\hline \multirow[t]{2}{*}{ Potassium } & o.d. & 28 & 4.13 & 0.29 & 27 & 4.28 & 0.344 & 27 & 0.160 & 0.395 & 0.035 & & I \\
\hline & t.i.d. & 18 & 4.17 & 0.384 & 15 & 4.25 & 0.363 & 15 & 0.119 & 0.413 & 0.202 & & $\mathrm{NC}$ \\
\hline \multirow[t]{2}{*}{ Magnesium } & $o . d$. & 25 & 0.8 & 0.0913 & 23 & 0.8 & 0.106 & 23 & -0.0129 & 0.102 & 0.572 & & $\mathrm{NC}$ \\
\hline & t.i.d. & 16 & 0.806 & 0.0562 & 12 & 0.783 & 0.0677 & 12 & -0.0264 & 0.0537 & 0.135 & & $\mathrm{NC}$ \\
\hline \multirow[t]{2}{*}{ Creatinine } & o.d. & 29 & 67.2 & 12.2 & 27 & 69.6 & 16.9 & 27 & 3.67 & 12.9 & 0.131 & 0.156 & $\mathrm{NC}$ \\
\hline & t.i.d. & 18 & 69.9 & 17.5 & 15 & 65.4 & 15.7 & 15 & -0.571 & 15.9 & 0.871 & 0.889 & $\mathrm{NC}$ \\
\hline
\end{tabular}

BMI: body mass index; o.d.: once-daily; t.i.d.: thrice-daily; FVC: forced vital capacity; FEV1: forced expiratory volume in one second; FEF25-75\%: forced mid-expiratory flow; Score: clinical score; WCC: white cell count; Neut.: neutrophil count; CRP: C-reactive protein; I: increased; D: decreased; NC: no change.

Table 2. - Between group comparisons and equivalence tests

\begin{tabular}{|c|c|c|c|c|c|c|c|c|c|c|}
\hline & & \multirow[t]{2}{*}{$\mathrm{n}$} & \multicolumn{2}{|c|}{$\%$ change } & \multicolumn{3}{|c|}{$\begin{array}{l}\text { Estimate of effect size } \\
\text { (treatment difference) }\end{array}$} & \multicolumn{2}{|c|}{$\begin{array}{l}\text { p-value for equivalence } \\
\text { (within } 10 \% \text { ) }\end{array}$} & \multirow[t]{2}{*}{$\begin{array}{l}\text { Conclusion } \\
(\alpha=0.025)\end{array}$} \\
\hline & & & mean & SD & mean & $\mathrm{SE}$ & $95 \% \mathrm{CI}$ & t-test & $\begin{array}{l}\text { Mann- } \\
\text { Whitney }\end{array}$ & \\
\hline BMI & o.d. & $\begin{array}{l}24 \\
13\end{array}$ & $\begin{array}{l}2.85 \\
2.85\end{array}$ & $\begin{array}{l}3.09 \\
3.86\end{array}$ & -0.007 & 0.978 & $-1.65-\infty$ & $<0.000001$ & & Eq. \\
\hline $\mathrm{FVC} \%$ & $\begin{array}{l}\text { o.d. } \\
\text { t.i.d. }\end{array}$ & $\begin{array}{l}30 \\
16\end{array}$ & $\begin{array}{l}32.6 \\
23.2\end{array}$ & $\begin{array}{l}43 \\
29\end{array}$ & 9.39 & 10.31 & $-7.86-\infty$ & 0.033 & 0.013 & Eq. \\
\hline FEV1 \% & $\begin{array}{l}\text { o.d. } \\
\text { t.i.d. }\end{array}$ & $\begin{array}{l}30 \\
16\end{array}$ & $\begin{array}{l}29.5 \\
25.5\end{array}$ & $\begin{array}{l}36.9 \\
31.8\end{array}$ & 3.94 & 9.48 & $-11.9-\infty$ & 0.340 & 0.385 & NS \\
\hline FEF $25-75 \%$ & $\begin{array}{l}\text { o.d. } \\
\text { t.i.d. }\end{array}$ & $\begin{array}{l}30 \\
16\end{array}$ & $\begin{array}{l}26.2 \\
25\end{array}$ & $\begin{array}{l}44.3 \\
37.7\end{array}$ & 1.18 & 11.3 & $-17.8-\infty$ & 0.164 & & NS \\
\hline Score & $\begin{array}{l}\text { o.d. } \\
\text { t.i.d. }\end{array}$ & $\begin{array}{c}21 \\
9\end{array}$ & $\begin{array}{l}-47.4 \\
-51.4\end{array}$ & $\begin{array}{l}29.7 \\
28.6\end{array}$ & 4.01 & 9.95 & $-\infty-20.8$ & 0.276 & & NS \\
\hline WCC & $\begin{array}{l}\text { o.d. } \\
\text { t.i.d. }\end{array}$ & $\begin{array}{l}25 \\
14\end{array}$ & $\begin{array}{l}-18 \\
-30.8\end{array}$ & $\begin{array}{l}27.7 \\
26.2\end{array}$ & 12.78 & 8.11 & $-\infty-26.4$ & 0.633 & 0.540 & NS \\
\hline Neut. $\%$ & $\begin{array}{l}\text { o.d. } \\
\text { t.i.d. }\end{array}$ & $\begin{array}{l}25 \\
14\end{array}$ & $\begin{array}{l}-13.4 \\
-15.7\end{array}$ & $\begin{array}{l}17.9 \\
13.4\end{array}$ & 2.29 & 5.52 & $-\infty-11.6$ & 0.085 & 0.159 & NS \\
\hline CRP & $\begin{array}{l}\text { o.d. } \\
\text { t.i.d. }\end{array}$ & $\begin{array}{l}23 \\
15\end{array}$ & $\begin{array}{l}-45.3 \\
-25.8\end{array}$ & $\begin{array}{l}38.8 \\
34.1\end{array}$ & -19.5 & 11.0 & $-\infty-1.09$ & 0.005 & 0.002 & Eq. \\
\hline Potassium & $\begin{array}{l}\text { o.d. } \\
\text { t.i.d. }\end{array}$ & $\begin{array}{l}27 \\
15\end{array}$ & $\begin{array}{l}4.28 \\
3.4\end{array}$ & $\begin{array}{l}9.91 \\
9.93\end{array}$ & 0.873 & 2.82 & $-4.80-6.55$ & 0.0002 and 0.001 & & Eq. \\
\hline Magnesium & $\begin{array}{l}\text { o.d. } \\
\text { t.i.d. }\end{array}$ & $\begin{array}{l}23 \\
12\end{array}$ & $\begin{array}{l}-1 \\
-3.29\end{array}$ & $\begin{array}{c}13.4 \\
6.69\end{array}$ & 2.29 & 4.32 & $-6.54-11.11$ & 0.004 and 0.042 & 0.004 and 0.007 & Eq. \\
\hline Creatinine & $\begin{array}{l}\text { o.d. } \\
\text { t.i.d. }\end{array}$ & $\begin{array}{l}27 \\
15\end{array}$ & $\begin{array}{l}5.45 \\
0.898\end{array}$ & $\begin{array}{l}18.4 \\
27.6\end{array}$ & 4.55 & 6.43 & $-8.4-17.5$ & 0.014 and 0.200 & 0.004 and 0.200 & NS \\
\hline
\end{tabular}

CI: confidence interval; $\infty$ : infinity; BMI: body mass index; o.d.: once-daily; t.i.d.: thrice-daily; FVC: forced vital capacity; FEV1: forced expiratory volume in one second; FEF 25-75\%: forced mid-expiratory flow; Score: clinical score; WCC: white cell count; Neut.: neutrophil count; CRP: C-reactive protein; Eq.: equivalent; NS: not significant. 
Table 3. - Pharmacokinetic parameters

\begin{tabular}{|c|c|c|c|}
\hline & \multirow[t]{2}{*}{ Mean } & \multicolumn{2}{|c|}{ Confidence limit } \\
\hline & & $-95 \%$ & $+95 \%$ \\
\hline \multicolumn{4}{|l|}{ Once-daily group } \\
\hline 60 -min level $\mathrm{mg} \cdot \mathrm{L}^{-1}$ & 19.9 & 16.9 & 23.0 \\
\hline 6-h level $\mathrm{mg} \cdot \mathrm{L}^{-1}$ & 2.7 & 2.0 & 3.5 \\
\hline $\begin{array}{l}\text { Time when level equaled } \\
1 \mathrm{mg} \cdot \mathrm{L}^{-1} \mathrm{~h}\end{array}$ & 10.4 & 7.9 & 12.9 \\
\hline $\mathrm{k} \mathrm{h}^{-1}$ & 0.36 & 0.32 & 0.40 \\
\hline Half-life $h$ & 1.9 & 1.7 & 2.2 \\
\hline $\begin{array}{l}\text { Maximum tobramycin } \\
\text { level } \mathrm{mg} \cdot \mathrm{L}^{-1}\end{array}$ & 29.1 & 24.5 & 33.7 \\
\hline Repeat 60 -min level $\mathrm{mg} \cdot \mathrm{L}^{-1}$ & 25.6 & 19.5 & 31.7 \\
\hline Repeat 6-h level $\mathrm{mg} \cdot \mathrm{L}^{-1}$ & 3.3 & 2.2 & 4.5 \\
\hline $\begin{array}{l}\text { Time when level equalled } \\
1 \mathrm{mg} \cdot \mathrm{L}^{-1} \mathrm{~h}\end{array}$ & 9.9 & 6.7 & 13.2 \\
\hline $\mathrm{k}$ & 0.38 & 0.32 & 0.44 \\
\hline Half-life $h$ & 2.0 & 1.5 & 2.4 \\
\hline $\begin{array}{l}\text { Maximum tobramycin } \\
\text { level } \mathrm{mg} \cdot \mathrm{L}^{-1}\end{array}$ & 41.0 & 29.9 & 52.2 \\
\hline \multicolumn{4}{|l|}{ Twice-daily group } \\
\hline Peak level $\mathrm{mg} \cdot \mathrm{L}^{-1}$ & 10.5 & 8.9 & 12.1 \\
\hline Trough level $\mathrm{mg} \cdot \mathrm{L}^{-1}$ & 1.3 & 1.1 & 1.6 \\
\hline $\mathrm{k} \mathrm{h}^{-1}$ & 0.37 & 0.34 & 0.40 \\
\hline Half-life $\mathrm{h}$ & 1.9 & 1.7 & 2.0 \\
\hline Repeat peak level $\mathrm{mg} \cdot \mathrm{L}^{-1}$ & 9.3 & 8.0 & 10.6 \\
\hline Repeat trough level $\mathrm{mg} \cdot \mathrm{L}^{-1}$ & 1.3 & 0.9 & 1.7 \\
\hline $\mathrm{k}$ & 0.36 & 0.28 & 0.44 \\
\hline Half-life $h$ & 2.0 & 1.5 & 2.5 \\
\hline
\end{tabular}

$\mathrm{k}$ : elimination rate constant.

aminoglycosides in $\mathrm{CF}$ that describes nephrotoxicity [16-24]. There was no significant change in serum creatinine or magnesium with treatment in either group in this study. There was a small but clinically insignificant rise in serum potassium in the o.d. group. o.d. treatment was equivalent to t.i.d. dosing for changes in mean serum potassium and magnesium levels.

Patients with CF are at risk of aminoglycoside ototoxicity due to high total drug dose, long duration of therapy, high antibiotic serum concentrations, and previous therapy with ototoxic drugs [25]. Only one out of 18 patients tested from the o.d. group and one out of 10 patients from the t.i.d. group had an impaired audiogram after treatment. The present results must be viewed with caution since not all the patients in the study were tested. Aminoglycoside antibiotics affect high frequency hearing $(15,000$ $20,000 \mathrm{~Hz}$ ) before lower frequencies $(1,000-8,000 \mathrm{~Hz})$. The study was not designed to detect changes to the high frequencies. Two previous studies in CF patients reported vestibular toxicity with the highest peak drug concentrations $[22,23]$. The potential for very high peak concentrations with o.d. dosing was minimized in the study by extending the duration of administration of tobramycin from $20-60 \mathrm{~min}$. Vestibular toxicity was assessed by the use of a symptom questionnaire and was not found in either group.

Aminoglycosides are the most commonly prescribed antibiotics for treatment of respiratory exacerbations in patients with CF [26]. An audit of antibiotic usage in the unit found that $40 \%$ of treatment courses included an aminoglycoside. Efficacy is concentration-dependent. The higher peak serum aminoglycoside levels achieved with o.d. dosing should be more effective [1]. The greater drug-free period with $o . d$. dosing should reduce toxicity, because it allows tissue drug concentration to fall. Greater convenience for patients and staff, and cheaper therapeutic drug level monitoring are further advantages of $o . d$. administration.

The number of $\mathrm{CF}$ patients receiving treatment at home is increasing [27]. In addition, an o.d. antibiotic dose regimen is less disruptive to normal life. Therefore, despite the lack of evidence to support the efficacy and safety of an o.d. regimen and the lack of a validated method of monitoring plasma drug concentrations, some CF centres have introduced its use into routine practice for home intravenous antibiotic programmes. Efficacy and safety data are therefore needed. WooD et al. [28] found a twice-daily tobramycin dosing regimen in nine adult patients with $\mathrm{CF}$ showed equal efficacy to, and less ototoxicity than, a t.i.d. regimen in 20 matched patients. They suggested that higher target peak levels might be achieved and interdose intervals increased, but that this would require further prospective studies.

In non-CF patients, o.d. administration of aminoglycosides is as effective and less nephrotoxic than t.i.d. administration [4]. An o.d. regimen in these patients is simplified by a validated plasma concentration monitoring nomogram [29]. The use of aminoglycosides in CF differs with the size of the doses used. Even taking into account the larger volume of distribution, a $10 \mathrm{mg} \cdot \mathrm{kg}^{-1}$ dose is likely to produce a higher maximum concentration than the lower doses used in non-CF patients. Most CF patients also have longer and multiple courses of treatment. Treatment in non-CF patients is usually a single course. Therefore, confirmation was needed that these differences would not result in a greater incidence of side-effects.

There is no validated method for drug-level monitoring of o.d. aminoglycosides in $\mathrm{CF}$, although the principles of monitoring treatment remain the same as for t.i.d. administration. Peak concentration must be high enough to ensure efficacy and the trough concentration must be low enough to avoid accumulation.

Pharmacokinetic studies in CF show that the elimination half-life is $\sim 2 \mathrm{~h}$ [30]. Assuming first-order pharmacokinetics, tobramycin concentrations will fall below $1 \mathrm{mg} \cdot \mathrm{L}^{-1}$ after six half-lives, leaving a period of $\sim 12 \mathrm{~h}$ when there are sub-inhibitory plasma concentrations. The in vitro postantibiotic effect for tobramycin is only $\sim 3-4 \mathrm{~h}$ [31]. The in vivo postantibiotic effect duration is reported to be 3-8 h for $P$. aeruginosa [32], but may decrease after subsequent doses. Thus, there is a possibility that bacterial regrowth will reduce the efficacy of treatment.

The pharmacokinetic results in this study showed a mean elimination half-life of $1.9 \mathrm{~h}$. This value was the same for both groups and did not change between the first and second week. The mean estimated time at which the serum drug concentration fell to $\leqslant 1 \mathrm{mg} \cdot \mathrm{L}^{-1}$ in the o.d. group was $11.4 \mathrm{~h}$ after the start of the infusion, leaving a 12 -h period at the end of the dosing interval when the serum drug concentration was very close to zero. This "drug-free interval" is an important 
goal of o.d. administration of aminoglycosides, as reduced drug tissue accumulation provides a theoretical reason for reduced end-organ toxicity. It also allows any bacterial adaptive resistance to be overcome. During this 12-h drug-free interval the postantibiotic effect may not fully compensate for the low drug concentrations. The period at the end of the dosing interval without either antibiotic activity or postantibiotic effect did not appear to have any clinical implications in this study. It may not be significant, as treatment with aminoglycosides in $\mathrm{CF}$ is usually accompanied by a second antibiotic.

In conclusion, this is the first study to evaluate the efficacy and toxicity of once-daily tobramycin in adult patients with $\mathrm{CF}$ using a dose of $10 \mathrm{mg} \cdot \mathrm{kg}^{-1}$. It reports the largest population with $\mathrm{CF}$ in whom once- versus thrice-daily aminoglycoside therapy has been compared. The study represents the maximum number that could be recruited at an adult centre, serving about 250 patients. This single-centre study suggests that the two treatment regimens are equally effective and safe in the treatment of Pseudomonas aeruginosa respiratory exacerbations in adult patients with cystic fibrosis. The null hypothesis that oncedaily treatment may be worse than thrice-daily treatment for all the prescribed endpoints, could not be rejected because of insufficient power. Therefore, before once-daily dosing can be fully recommended, large multicentre studies are needed to substantiate these results. There is also a need for a validated nomogram in once-daily aminoglycoside treatment regimens, to maximize efficacy and minimize toxicity.

\section{Appendix: formulae}

Elimination rate constant $\left(\mathrm{k}\left(\mathrm{h}^{-1}\right)\right)$ :

$$
\mathrm{k}=\frac{\ln (\mathrm{C} 1)-\ln (\mathrm{C} 2)}{\mathrm{TI}}
$$

Elimination half-life $\left(\mathrm{t}^{1} \frac{1}{2}(\mathrm{~h})\right)$ :

$$
\mathrm{t} 1 / 2=\frac{0.693}{\mathrm{k}}
$$

Estimated time when serum tobramycin concentration is $1 \mathrm{mg} \cdot \mathrm{L}^{-1}$ :

$$
\frac{\ln (\mathrm{C} 1)}{\mathrm{k}}
$$

Estimated concentration at the end of the $60-\mathrm{min}$ infusion (o.d. group):

$$
\mathrm{C}_{1} \mathrm{e}^{\mathrm{k}}
$$

where $\mathrm{C}_{1}$ is the measured serum tobramycin concentration $60 \mathrm{~min}$ after the end of the infusion, $\mathrm{C}_{2}$ is the measured serum tobramycin concentration $5 \mathrm{~h}$ after $\mathrm{C} 1$ and $\mathrm{TI}$ is the time interval between samples (h).

Acknowledgements. The authors gratefully acknowledge the help of the nursing team on $G$ ward at Seacroft and the Dept of Hearing Services at St. James's Hospital for performing the audiograms.

\section{References}

1. Deziel-Evans LM, Murphy JE, Job ML. Correlation of pharmacokinetic indices with therapeutic outcome in patients receiving aminoglycosides. Clin Pharm 1986; 5: 319-324.

2. Wood CA, Norton DR, Kohlhepp SJ, et al. The influence of tobramycin dosage regimens on nephrotoxicity, ototoxicity, and antibacterial efficacy in a rat model of subcutaneous abscess. J Infect Dis 1988; 158: 13-22.

3. Verpooten GA, Guiliano RA, Verbist L, Eestermans G, DeBroe ME. Once daily dosing decreases renal accumulation of gentamicin and netilmicin. Clin Pharmacol Ther 1989; 45: 22-27.

4. Barza M, Ioannidis JPA, Cappelleri JC, Lau J. Single or multiple daily doses of aminoglycosides: a metaanalysis. BMJ 1996; 312: 338-345.

5. Touw DJ. Clinical pharmacokinetics of antimicrobial drugs in cystic fibrosis. Pharm World Sci 1998; 20: $149-160$.

6. Horrevorts AM, Driessen O, Michel MF, Kerrebijn KF. Pharmacokinetics of antimicrobial drugs in cystic fibrosis: aminoglycoside antibiotics. Chest 1999; 94: 120S-125S.

7. Kelly WH, Lovato C. Antibiotic use in cystic fibrosis. Drug Intell Clin Pharm 1984; 18: 772-783.

8. Prins JM, Buller HR, Kuijper EJ, Tanger A, Speelman P. Once $v$. thrice daily gentamicin in patients with serious infections. Lancet 1993; 341: 335-339.

9. Conway SP, Pond MN, Bowler I, et al. The chest radiograph in cystic fibrosis: a new scoring system compared with the Chrispin-Norman and Brasfield scores. Thorax 1994; 49: 860-862.

10. Shwachman H, Kulczycki LL. Long-term study of 105 patients with cystic fibrosis: studies made over a 5 to 14 year period. Am J Dis Child 1958; 96: 6-15.

11. Conway SP, Miller MG, Ramsden C, Littlewood JM. Intensive treatment of a pseudomonas chest infection in cystic fibrosis: a comparison of tobramycin and ticarcillin, and netilmycin. Acta Pediatr Scand 1985; 74: 107-113.

12. Zaske D. Aminoglycosides. In: Evans WE, Schentag JJ, Jusko WJ, eds. Applied Pharmacokinetics. Principles of Therapeutic Drug Monitoring. 2nd Edn. Washington, Applied Therapeutics Inc., 1986; pp. 331-381.

13. Aminoglycosides once daily? Drug Ther Bull 1997; 35: $36-37$.

14. Sawchuk RJ, Zaske DE, Cipolle RJ, Wargin WA, Strater RG. Kinetic model for gentamicin dosing with the use of individual patient parameters. Clin Pharmacol Ther 1977; 21: 362-369.

15. Sawchuk RJ, Zaske DE. Pharmacokinetics of dosing regimens which utilise multiple intravenous infusions: gentamicin in burn patients. $J$ Pharmacokinet Biopharm 1976; 4: 183-195.

16. Bragonier R, Brown NM. The pharmacokinetics and toxicity of once-daily tobramycin therapy in children with cystic fibrosis. J Antimicrob Chemother 1998; 42: 103-106.

17. Bates RD, Nahata MC, Jones JW, et al. Pharmacokinetics and safety of tobramycin after once-daily administration in patients with cystic fibrosis. Chest 1997; 112: 1208-1213.

18. Beringer PM, Vinks AA, Jelliffe RW. Pharmacokinetics of once-daily amikacin dosing in patients 
with cystic fibrosis. J Antimicrob Chemother 1998; 41: 142-144.

19. Canis F, Husson MO, Turck D, et al. Pharmacokinetics and bronchial diffusion of single daily dose amikacin in cystic fibrosis patients. $J$ Antimicrob Chemother 1997; 39: 431-433.

20. Canis F, Trivier D, Vic P, Ategbo S, Turck D, Husson MO. Comparison of the pharmacokinetics of tobramycin administered in a single daily dose or in three doses in cystic fibrosis. Pathol Biol 1998; 46: 449-451.

21. Guglielmo BJ, Quan LA, Stulbarg MS. Pharmacokinetics of once-daily versus thrice daily tobramycin in cystic fibrosis patients. J Antimicrob Chemother 1996; 37: 1040-1042.

22. Powell SH, Thompson WL, Luthe MA, et al. Oncedaily vs. continuous aminoglycoside dosing: efficacy and toxicity in animal and clinical studies of gentamicin, netilmicin, and tobramycin. J Infect Dis 1983; 147: 918-932.

23. Smith DL, Stableforth DE, Geddes AM. Evaluation of a once-daily netilmicin regimen in the treatment of cystic fibrosis. J Antimicrob Chemother 1994; 33: 191193.

24. Vic $\mathrm{P}$, Ategbo $\mathrm{S}$, Turck $\mathrm{D}$, et al. Tolerance, pharmacokinetics and efficacy of once daily amikacin for treatment of Pseudomonas aeruginosa pulmonary exacerbations in cystic fibrosis patients. Eur $J$ Pediatr 1996; 155: 948-953.

25. Moore RD, Smith CR, Lietman PS. Risk factors for the development of auditory toxicity in patients receiving antibiotics. J Infect Dis 1984; 149: 23-30.

26. Taylor RFH, Hodson ME. Cystic fibrosis: antibiotic prescribing practices in the United Kingdom and Eire. Respir Med 1993; 87: 535-539.

27. Pond MN, Newport M, Joanes D, Conway SP. Home $v$ hospital intravenous antibiotic therapy in the treatment of young adults with cystic fibrosis. Eur Respir $J$ 1994; 7: 1640-1644.

28. Wood PJ, Ioannides-Demos LL, Lee LICS, et al. Minimisation of aminoglycoside toxicity in patients with cystic fibrosis. Thorax 1996; 51: 369-373.

29. Nicolau DP, Freeman CD, Belliveau PP, Nightingale $\mathrm{CH}$, Ross JW, Quintiliani R. Experience with a oncedaily aminoglycoside program administered to 2,184 adult patients. Antimicrob Agents Chemother 1995; 39: 650-655.

30. Kelly WH, Menendez R, Fan L, Murphy SG. Pharmacokinetics of tobramycin in cystic fibrosis. J Pediatr 1982; 100: 318-321.

31. Spivey JM. The post antibiotic effect. Clin Pharm 1992; 11: 865-875.

32. Vogelman SV, Craig WA. Postantibiotic effects. J Antimicrob Chemother 1985; 15: 37-46. 